\begin{tabular}{|c|l|}
\hline Title & $\begin{array}{l}\text { Calcium carbonate precipitation in compacted bentonite using electromigration reaction method and its application to } \\
\text { estimate the ion activity coefficient in the porewater }\end{array}$ \\
\hline Author(s) & Rachmadetin, Jaka; Mizuto, Masay a; Tanaka, Shingo; Kozaki, Tamotsu; W atanabe, Naoko \\
\hline Citation & $\begin{array}{l}\text { Journal of nuclear science and technology, 56(11), 959-970 } \\
\text { https://doi.org/10.1080/00223131.2019.1630020 }\end{array}$ \\
\hline Issue Date & 2019-11 \\
\hline Doc URL & http://hdl.handle.net/2115/79646 \\
\hline Rights & $\begin{array}{l}\text { This is an A ccepted Manuscript of an article published by Taylor \& Francis in Journal of nuclear science and } \\
\text { technology on Nov. 2019, avail lable online: http:/Www.tandfonline.com/10.1080/00223131.2019.1630020. }\end{array}$ \\
\hline Type & article (author version) \\
\hline File Information & manuscript-JNST-jaka.pdf \\
\hline
\end{tabular}

Instructions for use 
Calcium carbonate precipitation in compacted bentonite using electromigration reaction method and its application to estimate the ion activity coefficient in the porewater

Jaka Rachmadetin $^{a b}$, Masaya Mizuto $^{a}$, Shingo Tanaka ${ }^{a}$, Tamotsu Kozaki ${ }^{a *}$, Naoko Watanabe ${ }^{a}$

${ }^{a}$ Division of Energy and Environmental Systems, Graduate School of Engineering, Hokkaido University, Kita 13 Nishi 8, Kita-ku, Sapporo, Hokkaido 060-8628, Japan;

${ }^{b}$ Radioactive Waste Technology Center, National Nuclear Energy Agency (BATAN), Kawasan Puspiptek Serpong, South Tangerang, Indonesia

*Corresponding author: kozaki@eng.hokudai.ac.jp 


\title{
Calcium carbonate precipitation in compacted bentonite using electromigration reaction method and its application to estimate the ion activity coefficient in the porewater
}

\begin{abstract}
In the safety assessment of radioactive waste disposal, it is critical to understand the porewater chemistry in compacted bentonite in order to predict long-term migration behavior of radionuclides in the engineered barrier. This study estimates the activity coefficients of dissolved ions in the porewater of compacted bentonite from the concentrations of ions at which $\mathrm{CaCO}_{3}$ precipitation occurred. Solutions containing $\mathrm{CaCl}_{2}$ and $\mathrm{NaHCO}_{3}$ were introduced under electrical potential gradient from the opposite sides of the compacted Na-bentonite packed at the dry density of $1.0 \mathrm{~kg} / \mathrm{dm}^{3}$. After the electromigration, the spatial distribution of ions along the compacted bentonite sample was determined. Sequential extraction method was developed to distinctly determine the concentrations of free ions in the porewater and in solid phase in bentonite. The results show that the exchangeable $\mathrm{Na}^{+}$ions were progressively replaced by the incoming $\mathrm{Ca}^{2+}$ ions, and the compacted bentonite sample can be divided into three zones: $\mathrm{Ca}-\mathrm{Ca}-\mathrm{Na}-$, and $\mathrm{Na}$-bentonite zones. Precipitates of $\mathrm{CaCO}_{3}$ were observed both in $\mathrm{Ca}$ - and $\mathrm{Ca} / \mathrm{Na}$-bentonite zones. The experimentally determined activity coefficients were at least smaller by a factor of three compared to the theoretical approximation calculated using PHREEQC code assuming dilute-solution conditions with no electrostatic interactions between ions and bentonite surface.
\end{abstract}

Keywords: radioactive waste management; solubility; migration; bentonite; calcium carbonate; porewater; activity coefficient 


\section{Introduction}

Geological disposal is recognized as safe and secure means to dispose of high-level radioactive waste [1]. It requires multiple safety functions to isolate radionuclides in the waste forms from the biosphere [2]. A multi-barrier approach consisting of a series of engineered and natural barriers is adopted to contain the waste for a long period of time. Compacted bentonite is one part of the engineered barrier system, which is expected to provide the protection for the waste forms from the physical and chemical processes and to limit the rate of transport of radionuclides that may be released from the waste forms.

In the actual radioactive waste disposal facilities, perturbation of bentonite buffer may occur over time due to interactions with the surrounding materials. One of the potential perturbations is $\mathrm{CaCO}_{3}$ precipitation [3,4]. Cementitious materials are used in the structure of radioactive waste repository, and the leachate from them is rich with $\mathrm{Ca}^{2+}$ ions $[3,5]$. This leachate may also raise the $\mathrm{pH}$ of the surrounding environment and promote rock alteration that results in the release of $\mathrm{CO}_{3}{ }^{2-}$ ions [6]. The reaction of these two ions can generate $\mathrm{CaCO}_{3}$ precipitates, which may affect the transport of radionuclides by porosity clogging $[5,7,8]$ and/or incorporation of radionuclides in the precipitates $[9,10]$. Although $\mathrm{CaCO}_{3}$ precipitation has been studied extensively in bulk solution $[11,12]$ and in porous media [13-16], little is known about its behavior in compacted bentonite.

Montmorillonite, which is the major component of bentonite clays, has two types of pore spaces: interlayer space which is filled with interlayer water containing cations to compensate the excess negative charge of montmorillonite layers, and interparticle space which is filled with free porewater [17-20]. Due to the negative charge of montmorillonite layers, anions, including $\mathrm{HCO}_{3}{ }^{-} / \mathrm{CO}_{3}{ }^{2-}$ ions, are excluded 
from the interlayer space, thus the precipitation of $\mathrm{CaCO}_{3}$ is expected to occur only in the interparticle space where both $\mathrm{Ca}^{2+}$ and $\mathrm{CO}_{3}{ }^{2-}$ ions can be present in the porewater. Moreover, concentrations of ions in the interparticle porewater are also heterogeneous due to electric double layer effect. The ion activity product of $\mathrm{Ca}^{2+}$ and $\mathrm{CO}_{3}{ }^{2-}$ may not be high enough to form $\mathrm{CaCO}_{3}$ precipitates near the surface of the clay, and as a result, precipitation preferentially occurs in larger pores [15,21]. Micro-scale porewater chemistry controls the precipitation of $\mathrm{CaCO}_{3}$ in compacted bentonite, or reversely, analysis of the conditions under which precipitation takes place in compacted bentonite may provide insight into micro-scale porewater chemistry.

Studying the porewater chemistry in compacted bentonite is challenging because it is difficult to directly analyze it in-situ, and to sample it without potential alteration [22]. Experimental data of porewater composition have been obtained by water sampling with borehole instrumentation [23], extraction using squeezing techniques [24], and liquid displacement with a solution of known composition [25]. These data are often complemented with geochemical modelling assuming that the dissolved ions in porewater have the same activity coefficients as in bulk water [25-29]. However, it has been reported that the porewater behaves like solutions with high ionic strength due to interactions between the ions in porewater and montmorillonite surfaces [30]. This contradicts with the basic assumption that the ionic strength in compacted bentonite system is the same as in bulk water, and the lack of quantitative understanding on the activities of the ions in porewater in compacted bentonite system is limiting the advance of the discussion on migration behaviors and chemical reactions of ions.

The objective of this study is to determine the activity coefficients of dissolved ions in the porewater of compacted montmorillonite using $\mathrm{CaCO}_{3}$ precipitation 
processes as an indicator of activities of reacting ions. Electrokinetic method was used to enhance the migration of reacting ions because the hydraulic conductivity in compacted bentonite is very low (less than $10^{-11} \mathrm{~m} / \mathrm{s}$ ). This method has been used to study radionuclides migration [31-34] and gypsum $\left(\mathrm{CaSO}_{4}\right)$ precipitation in compacted bentonite [35]. Under the electrical potential gradient, $\mathrm{Ca}^{2+}$ ions migrate towards the cathode side while $\mathrm{HCO}_{3}{ }^{-} / \mathrm{CO}_{3}{ }^{2-}$ ions migrate towards the anode side in the opposite direction. As the process continues, $\mathrm{CaCO}_{3}$ precipitates are produced by a chemical reaction between $\mathrm{Ca}^{2+}$ and $\mathrm{HCO}_{3}{ }^{-} / \mathrm{CO}_{3}{ }^{2-}$ ions when the solution is oversaturated with respect to $\mathrm{CaCO}_{3}$ precipitates. A sequential extraction method was developed to separately quantify cations in the porewater in ionic forms from the precipitates in the solid phase. Activity coefficients were estimated assuming that after precipitation, the ionic activity product (IAP) is equal to the solubility product $\left(K_{s p}\right)$.

\section{Method}

\subsection{Materials}

Kunipia F (Kunimine Industries Co., Tokyo, Japan), which contains more than 95\% montmorillonite, was used as a starting bentonite material. All chemicals used in this study were of analytical grade (Junsei Chemical Co., Tokyo, Japan). Deionized water was prepared using EYELA Still Ace SA-2100E1 (Tokyo Rikakikai Co., Tokyo, Japan). The radioisotopes ${ }^{45} \mathrm{CaCl}_{2}$ and $\mathrm{NaH}^{14} \mathrm{CO}_{3}$ (PerkinElmer, Boston, USA) were obtained from Japan Radioisotope Association.

\subsection{Preparation of Saturated Compacted Na-Bentonite}

Kunipia $\mathrm{F}$ was purified to obtain a homoionized Na-montmorillonite with particle size 
between 75 and $150 \mu \mathrm{m}$ using the method described in detail elsewhere [36]. Compacted Na-montmorillonite was prepared to have the dry density of $1.0 \mathrm{~kg} / \mathrm{dm}^{3}$ in acrylic resin cells with both inner diameter and length of $20 \mathrm{~mm}$. The one end of the inner cylindrical cell was closed with stainless steel sintered filter having a pore size of $2 \mu \mathrm{m}$. Dry homoionized Na-bentonite was weighed to have a predetermined density and was placed into the cell from the other open end. A pressure was applied to pack the bentonite powder in the inner cylinder of the acrylic cell, then the open end was closed with the stainless-steel filter. The cells containing compacted bentonite sample were immersed in $0.7 \mathrm{M} \mathrm{NaHCO}_{3}$ solution in a closed container for 30 days at room temperature and atmospheric pressure.

\subsection{Electromigration Experiment}

The saturated sample was subjected to electromigration to enhance the migration of $\mathrm{Ca}^{2+}$ and $\mathrm{HCO}_{3}{ }^{-} / \mathrm{CO}_{3}{ }^{2-}$ ions in compacted montmorillonite so that they form precipitate $\mathrm{CaCO}_{3}$. The experimental setup is shown in Figure 1. The sample was set in a sample holder between the anode and the cathode reservoir containing $1 \mathrm{M} \mathrm{CaCl}_{2}$ and $0.7 \mathrm{M}$ $\mathrm{NaHCO}_{3}$, respectively. Saturated $\mathrm{ZnSO}_{4}$ solution and salt bridges were used so that the electrolysis cell is separated from the bentonite sample in order to avoid the water electrolysis effect.

Three kinds of electromigration experiments were carried out, using ${ }^{45} \mathrm{Ca},{ }^{14} \mathrm{C}$, and without tracers, respectively, to obtain the concentration profiles of $\mathrm{Ca}$ and $\mathrm{C}$ $\left(\mathrm{HCO}_{3}{ }^{-} / \mathrm{CO}_{3}{ }^{2-}\right)$ in the sample after migration and precipitation reaction. The solution used in the electromigration experiment for each tracer is summarized in Table 1. Prior to electromigration, the initial specific radioactivities $(\mathrm{cpm} / \mathrm{mmol})$ in the reservoir solutions were measured by radiation measurement. Then, an electric potential gradient 
was applied at a constant current of $5 \mathrm{~mA}$ at $298 \mathrm{~K}$ for 16 hours. The experiment was performed three times under the same experimental conditions. After the electromigration experiment, the acrylic cell was disassembled, and the bentonite sample was sliced to $0.5 \mathrm{~mm}$ thickness. The sliced montmorillonite samples were analyzed by sequential extraction, X-ray diffraction (XRD), and Scanning Electron Microscope equipped with Energy Dispersive X-ray Spectroscope (SEM/EDS).

\subsection{Sequential extraction of $\mathrm{Ca}$}

A sequential extraction procedure was developed to determine the concentrations of $\mathrm{Ca}$ in solution and in solid phase separately: $\mathrm{Ca}^{2+}$ ions dissolved as free ions in porewater, and $\mathrm{Ca}$ in the solid phase either as exchangeable cations in the interlayer of bentonite or as $\mathrm{CaCO}_{3}$ precipitates. The first extraction used saturated $\mathrm{CaCO}_{3}$ solution to only extract the free $\mathrm{Ca}^{2+}$ ions without dissolving $\mathrm{CaCO}_{3}$ precipitates. The second extraction used 1 $\mathrm{M} \mathrm{HCl}$ to target the remaining $\mathrm{Ca}$ fractions in the solid phase in the interlayer of montmorillonite and in $\mathrm{CaCO}_{3}$ precipitates.

Prior to using this method with the samples after the electromigration experiment, recoveries of the $\mathrm{Ca}^{2+}$ ions in porewater and in the interlayer of montmorillonite were tested. Saturated $\mathrm{CaCO}_{3}$ solution was prepared by stirring $\mathrm{CaCO}_{3}$ powder in deionized water for 1 day at room temperature and atmospheric pressure. The resulting solution was filtered with a $0.45 \mu \mathrm{m}$ membrane (Advantec, Tokyo, Japan) prior to use. Suspensions of $0.25 \mathrm{~g}$ dry Ca-bentonite and $1 \mathrm{ml} \mathrm{CaCl}_{2}$ solution was prepared with a known radioactivity distribution of ${ }^{45} \mathrm{Ca}^{2+}$ as free and as exchangeable ions. They were mixed with $10 \mathrm{ml}$ saturated $\mathrm{CaCO}_{3}$ solution and shaked for 1 hour, then the supernatant was collected after centrifuging at 10,000 rpm $(12,000 \mathrm{~g})$ for 10 minutes. Extraction with $10 \mathrm{ml}$ saturated $\mathrm{CaCO}_{3}$ solution was repeated one more time, 
similarly the supernatant was collected. After saturated $\mathrm{CaCO}_{3}$ solution was removed, $10 \mathrm{ml}$ of $1 \mathrm{M} \mathrm{HCl}$ were added to the sample and mixed in a shaker for 24 hours. The supernatant was then collected by centrifuging the sample at $10,000 \mathrm{rpm}(12,000 \mathrm{~g})$ for 10 minutes. The extraction with $1 \mathrm{M} \mathrm{HCl}$ was repeated one more time as well. Each of the supernatants was then ultra-filtered (USY-1 MWCO 10,000, Advantec, Tokyo, Japan) to remove colloidal particles of bentonite prior to radiation measurement of the ${ }^{45} \mathrm{Ca}^{2+}$ radioactivities with Aloka AccuFlex LSC-8000 (Hitachi, Tokyo, Japan). The recovery tests were conducted in duplicate.

This sequential extraction was applied to each of the sliced bentonite samples from experiment 1 which used ${ }^{45} \mathrm{Ca}$ as a tracer. The concentration of $\mathrm{Ca}^{2+}$ ions was calculated using the ratio of the ${ }^{45} \mathrm{Ca}^{2+}$ radioactivities in the filtrates to the initial specific radioactivities previously determined by radiation measurement.

\subsection{Concentration profiles of other ions}

The same supernatant from sequential extraction in experiment 1 was subjected to ICPAES measurement (ICPE-9000, Shimadzu, Kyoto, Japan) to determine the concentration of $\mathrm{Na}^{+}$ions. Each of the sliced bentonite samples was mixed with $10 \mathrm{ml}$ deionized water for 30 minutes in a closed bottle at room temperature and atmospheric pressure. The $\mathrm{pH}$ of the slurry was measured using a glass electrode (Laqua F-72, Horiba, Kyoto, Japan).

Free and total $\mathrm{H}^{14} \mathrm{CO}_{3}{ }^{-14} \mathrm{CO}_{3}{ }^{2-}$ concentrations were determined by extraction with saturated $\mathrm{CaCO}_{3}$ solution and $0.5 \mathrm{M} \mathrm{NaHCO}_{3}$, respectively. The total $\mathrm{H}^{14} \mathrm{CO}_{3}^{-}$ ${ }^{14} \mathrm{CO}_{3}{ }^{2-}$ concentrations were checked with direct measurement of the ${ }^{14} \mathrm{C}$ radioactivities. The sliced bentonite sample from experiment 2 with ${ }^{14} \mathrm{C}$ was divided into two. A portion of each was added with $5 \mathrm{ml}$ saturated $\mathrm{CaCO}_{3}$ solution and $0.5 \mathrm{M}$ 
$\mathrm{NaHCO}_{3}$, then they are mixed in a shaker for 1 and 24 hour, respectively.

Centrifugation, filtration, and measurement of the concentration of $\mathrm{H}^{14} \mathrm{CO}_{3}{ }^{-1}{ }^{14} \mathrm{CO}_{3}{ }^{2-}$ was carried out with the same procedure for ${ }^{45} \mathrm{Ca}^{2+}$.

\subsection{XRD and SEM/EDS Analysis}

XRD analysis was carried out to get the information about the polymorph of $\mathrm{CaCO}_{3}$ precipitates. Sliced bentonite samples from experiment 3 without tracers were vacuum dried at $378 \mathrm{~K}$ and then ground into powder with mortar and pestle. The XRD analyses of the powdered samples were conducted using Rigaku RU-300 X-ray diffractometer with $\mathrm{Cu} \mathrm{K} \alpha$ radiation (Rigaku, Tokyo, Japan). The scanning range was $2 \theta=5$ to 80 degrees with a step scan 0.05 and scanning speed of $1 \mathrm{~s}$ per scan.

The deposit of $\mathrm{CaCO}_{3}$ precipitates was analysed with a SEM/EDS. A portion of sliced bentonite sample from experiment 3 without tracers was placed onto a piece of double-sided carbon tape on a SEM stub. The morphology and elemental mapping for $\mathrm{Si}, \mathrm{Ca}, \mathrm{Al}, \mathrm{Mg}$ and $\mathrm{Na}$ on sliced bentonite samples were observed in perpendicular to the electromigration direction using JSM-7001FA (JEOL, Tokyo, Japan) with beam energy of $15 \mathrm{kV}$.

\section{Results}

\subsection{Sequential extraction test}

Table 2 summarizes the result of the tested sequential extraction. The recoveries of the free ${ }^{45} \mathrm{Ca}^{2+}$ ions in the solution phase from the first and second extraction were 92.9 and $1.3 \%$ in average, respectively. Majority of ${ }^{45} \mathrm{Ca}^{2+}$ ions were extracted in the first extraction with saturated $\mathrm{CaCO}_{3}$ solution. The amount of ${ }^{45} \mathrm{Ca}^{2+}$ extracted in the first 
extraction can be approximated as the free ions in the porewater. The recoveries of extraction of exchangeable ${ }^{45} \mathrm{Ca}^{2+}$ ions by $\mathrm{HCl}$ were $97.1 \%$ in average. This result shows that only free $\mathrm{Ca}^{2+}$ ions were extracted in the first extraction with saturated $\mathrm{CaCO}_{3}$ solution, while exchangeable ${ }^{45} \mathrm{Ca}^{2+}$ ions remained in the interlayer of montmorillonite. Therefore, the proposed sequential extraction can be applied to distinctly determine the amount of ${ }^{45} \mathrm{Ca}^{2+}$ ions in the liquid and in the solid phase.

\subsection{Spatial distribution of ions in bentonite after the electromigration}

Temporal spatial distribution of dissolved and solid phase of $\mathrm{Ca}^{2+}$ and $\mathrm{Na}^{+}$ions in compacted bentonite was determined by the sequential extraction method after 16 hours electromigration experiment, and is depicted in Figure 2. Initially before the electromigration experiment, only $\mathrm{Na}^{+}$ions existed as both free and exchangeable cations all through the sample. Once the electromigration starts, these $\mathrm{Na}^{+}$ions were attracted by the negatively charged electrode in the cathode side and started to migrate towards the cathode side. On the other hand, $\mathrm{Ca}^{2+}$ ions entered the compacted bentonite from the reservoir ${ }^{45} \mathrm{CaCl}_{2}$ solution on the anode side. Consequently, through these transport processes, the initially existed $\mathrm{Na}^{+}$ions in the bentonite sample were progressively replaced from the anode side towards the cathode side by the incoming $\mathrm{Ca}^{2+}$ ions

Acid extractable cations, which represent the sum of the ions in the interlayer and in precipitates, show that the compacted bentonite sample can be divided into three zones based on their exchangeable cation composition. The left part of Figure 2, from 0 to $5.25 \mathrm{~mm}$ distance from the anode side, is the zone where almost all of the exchangeable $\mathrm{Na}^{+}$ions initially existed in the interlayer of bentonite were replaced by $\mathrm{Ca}^{2+}$ ions (hereafter Ca-bentonite zone). The zone in the center of the compacted 
bentonite from 5.25 to $9.75 \mathrm{~mm}$ distance from the anode side has the mixture of Cabentonite and Na-bentonite (hereafter $\mathrm{Ca}-/ \mathrm{Na}$-bentonite zone). Finally, the right part of Figure 2, from $9.75 \mathrm{~mm}$ towards the cathode side, is where the interlayer of bentonite contains only $\mathrm{Na}^{+}$ions (hereafter Na-bentonite zone). This zone remained as a Nabentonite type unchanged from initial state. The maximum amount of $\mathrm{Ca}^{2+}$ ions which can occupy the interlayer of bentonite is equal to the CEC value $(1.05 \mathrm{meq} / \mathrm{g}$-dry bentonite [35]). Therefore, the concentration of acid extractable $\mathrm{Ca}^{2+}$ ions which exceed the CEC value by approximately $0.25 \mathrm{meq} / \mathrm{g}$-dry bentonite in the Ca-bentonite zone is the evidence of the presence of $\mathrm{CaCO}_{3}$ precipitates.

The spatial distribution of $\mathrm{HCO}_{3}{ }^{-} / \mathrm{CO}_{3}{ }^{2-}$ in aqueous and solid phase is shown in Figure 3. The solid phase $\mathrm{HCO}_{3}{ }^{-} / \mathrm{CO}_{3}{ }^{2-}$, which is likely $\mathrm{CaCO}_{3}$ precipitates, was present in the Ca-bentonite zone and in the mixture of $\mathrm{Ca}-/ \mathrm{Na}$ - bentonite zone. The concentration of precipitates in the Ca-bentonite zone was approximately $0.12 \mathrm{mmol} / \mathrm{g}$ dry bentonite, which is consistent with the excess of acid extractable $\mathrm{Ca}^{2+}$ ions shown previously in Figure 2. A sharp decrease of $\mathrm{CaCO}_{3}$ precipitates profile can be seen in the $\mathrm{Ca} / \mathrm{Na}$-bentonite zone, suggesting this zone exhibits the precipitation reaction front, where $\mathrm{CaCO}_{3}$ is first formed. The concentration of free $\mathrm{HCO}_{3}{ }^{-} / \mathrm{CO}_{3}{ }^{2-}$ in the $\mathrm{Ca}-$ bentonite zone decreased to almost zero because it was consumed by the incoming $\mathrm{Ca}^{2+}$ to produce $\mathrm{CaCO}_{3}$ precipitates. However, the profile in Na-bentonite zone shows that it also has been depleted although no precipitation occurred in this zone because $\mathrm{Ca}$ ions had not arrived yet. The plausible explanation is that the electromigration velocity of $\mathrm{HCO}_{3}{ }^{-} / \mathrm{CO}_{3}{ }^{2-}$ is lower than the electroosmotic flow which made them migrate to the cathode side even with their negative charge. Another possibility is that a part of $\mathrm{HCO}_{3}{ }^{-}$ $/ \mathrm{CO}_{3}{ }^{2-}$ ions migrated to the cathode side as neutral $\mathrm{NaHCO}_{3}$ ions. However, discussion 
for this dynamic process requires additional experimental data and it is beyond the scope of the discussion in this paper.

\section{3. $\mathrm{pH}$ profile}

Figure 4 shows the spatial pH profile of dispersed sliced bentonite in deionized water. A peak in the Ca-/Na-bentonite zone could be attributed to the dissolution of amorphous $\mathrm{CaCO}_{3}$ precipitates when the sliced bentonite is dispersed in water. Indeed, the $\mathrm{CaCO}_{3}$ precipitates in this zone should be in more disordered phase than in the Na-bentonite zone because it is closer to the reaction front. From $x=7.75 \mathrm{~mm}$ distance towards the cathode side, the $\mathrm{pH}$ gradually increases which in line with the profile of free $\mathrm{HCO}_{3}{ }^{-}$ $/ \mathrm{CO}_{3}{ }^{2-}$ ions shown previously in Figure 3.

\subsection{XRD and SEM-EDS analysis}

Figure 5 shows SEM/EDS images of bentonite sample from the initial condition and sliced bentonite sample at $x=7.75 \mathrm{~mm}$ after the experiment as a representative of reaction zone samples. Ca-rich areas, shown by the bright spots in Ca-map image, were not observed in the Ca-map image of initial bentonite sample (Figure 5a). In contrast, Ca-rich areas sparsely distributed in bentonite were observed after the experiment (Figure 5b). These results clearly confirm that the electromigration experiment generates the $\mathrm{CaCO}_{3}$ precipitates. The diameter of the Ca-rich area from the Ca-map image was approximately $2 \mu \mathrm{m}$ (Figure 5c). The $\mathrm{Si}, \mathrm{Al}$, and $\mathrm{Mg}$-map images show that these elements were also detected in the Ca-rich areas, suggesting that the Ca-rich areas contained a mixture of $\mathrm{CaCO}_{3}$ precipitates and bentonite. 
Figure 6 shows the diffraction pattern of powder sample of sliced bentonite at $x$ $=0.5 \mathrm{~mm}$ after the experiment. The occurrence of the $\mathrm{CaCO}_{3}$ precipitates at this point has been confirmed in the above explained spatial distribution of $\mathrm{Ca}^{2+}$ and $\mathrm{HCO}_{3}{ }^{-} / \mathrm{CO}_{3}{ }^{2-}$. However, the diffraction pattern of the sliced bentonite sample agreed well with the reference Ca-bentonite peaks, and the peaks of calcite, the most stable crystalline $\mathrm{CaCO}_{3}$, cannot be distinctly observed. This result suggests that the $\mathrm{CaCO}_{3}$ precipitates formed after the electromigration experiment are amorphous, thus did not exhibit sharp diffraction peaks, while the crystalline phase of $\mathrm{CaCO}_{3}$ might not have been attained in the experiment.

\section{Discussion}

\subsection{Estimation of mean activity coefficient from electromigration experiment}

After $\mathrm{CaCO}_{3}$ precipitated, the porewater should be in equillibrium with respect to $\mathrm{CaCO}_{3}$ precipitates. It implies that the IAP of $\mathrm{Ca}^{2+}$ and $\mathrm{CO}_{3}{ }^{2-}$ is equal to the $K_{s p}$ of $\mathrm{CaCO}_{3}$ precipitates when assuming the activity of solid phase $\mathrm{CaCO}_{3}$ is unity, expressed by:

$$
I A P=\left[\mathrm{Ca}^{2+}\right] \gamma_{\mathrm{Ca}^{2+}}\left[\mathrm{CO}_{3}{ }^{2-}\right] \gamma_{\mathrm{CO}_{3}{ }^{2-}}=\mathrm{K}_{\mathrm{Sp} \mathrm{CaCO}_{3}}
$$

where $\left[\mathrm{Ca}^{2+}\right]$ and $\left[\mathrm{CO}_{3}{ }^{2-}\right]$ are the concentration of $\mathrm{Ca}^{2+}$ and $\mathrm{CO}_{3}{ }^{2-}$ ions, respectively, $\gamma_{\mathrm{Ca}^{2+}}$ and $\gamma_{\mathrm{CO}_{3}{ }^{2-}}$ are their respective activity coefficients.

According to Equation (1), the mean activity coefficients $\left(\gamma_{ \pm}\right)$of $\mathrm{Ca}^{2+}$ and $\mathrm{CO}_{3}{ }^{2-}$ ions can be directly obtained once the concentrations of $\mathrm{Ca}^{2+}$ and $\mathrm{CO}_{3}{ }^{2-}$ ions, and the value of $K_{s p \mathrm{CaCO}_{3}}$ are known. For this purpose, recalculation of the concentrations of $\mathrm{Ca}^{2+}$ and $\mathrm{CO}_{3}{ }^{2-}$ ions expressed in units per dry weight of bentonite to molarity in 
porewater is necessary. An important issue for this calculation is the distribution of water types for estimation of the fraction of porewater in water-compacted bentonite system. The porewater fraction for compacted bentonite with dry density of $1.0 \mathrm{~kg} / \mathrm{dm}^{3}$ was reported to be $0.36 \mathrm{ml} / \mathrm{g}$ dry bentonite [18]. The recalculation of the concentration of $\mathrm{CO}_{3}{ }^{2-}$ ions is, however, not as straightforward as $\mathrm{Ca}^{2+}$ ions since the speciation of $\mathrm{HCO}_{3}{ }^{-} / \mathrm{CO}_{3}{ }^{2-}$ depend on the $\mathrm{pH}$ value. For this consideration, the concentration of $\mathrm{CO}_{3}{ }^{2-}$ ions is calculated in a range of $\mathrm{pH}$ value for dispersed bentonite in water measured in this study.

The value for $K_{s p}$ depends on the mineral type and the temperature. There are six $\mathrm{CaCO}_{3}$ polymorphs: calcite, aragonite, vaterite, monohydrocalcite $\left(\mathrm{CaCO}_{3} \cdot \mathrm{H}_{2} \mathrm{O}\right)$, ikaite $\left(\mathrm{CaCO}_{3} \cdot 6 \mathrm{H}_{2} \mathrm{O}\right)$ and amorphous $\mathrm{CaCO}_{3}$ with the solubility decreasing from the former to the latter [37-41]. Of these $\mathrm{CaCO}_{3}$ polymorphs, the SEM/EDS images and diffraction patterns results strongly suggest that the amorphous $\mathrm{CaCO}_{3}$ is the most likely candidate polymorph. Recent study also reported that precipitation of $\mathrm{CaCO}_{3}$ occurred via amorphous $\mathrm{CaCO}_{3}$ as a pre-nucleation [12]. Moreover, confinement effect could stabilize amorphous $\mathrm{CaCO}_{3}$ [42]. The amorphous phase was also often used as solubility-limiting solid phase in the calculation of radionuclides solubilities and speciation for a conservative estimation $[43,44]$. The commonly employed $K_{s p}$ value of amorphous $\mathrm{CaCO}_{3}$ is $10^{-6.4}$ [40]. However, recent study reported that the value is $10^{-7.54}$ which is about an order of magnitude lower than the previously reported. The author reasoned that the previously higher $K_{s p}$ value might be due to the polyamorphism of $\mathrm{CaCO}_{3}[45]$. Therefore, those two $K_{s p}$ values are used in the mean activity coefficient calculation. 
The small pore effect could make the value of the $K_{s p}$ value higher than in bulk solution $[46,47]$. The pore size effect to the value of $K_{s p}$ can be estimated as $[15,48]$ :

$$
\frac{K_{s p_{\text {pore }}}}{K_{S p_{\text {bulk }}}}=\exp \left(\frac{2 V_{m} \gamma_{s l}}{R T r}\right)
$$

where $V_{m}$ is the molar volume of the precipitates $\left(\mathrm{m}^{3} / \mathrm{mol}\right), \gamma_{S l}$ is the interfacial free energy $\left(\mathrm{J} / \mathrm{m}^{2}\right), R$ is the ideal gas constant $(\mathrm{J} / \mathrm{mol} \cdot \mathrm{K}), T$ is the absolute temperature $(\mathrm{K})$, and $r$ is the radius of the pore (m). Using $V_{m}=3.69 \times 10^{-5} \mathrm{~m}^{3} / \mathrm{mol}$ which calculated from calcite density $=2.645 \mathrm{~g} / \mathrm{cm}^{3}, \gamma_{s l}=0.094 \mathrm{~J} / \mathrm{m}^{2}$ [49], and $r=15.9 \mathrm{~nm}$ from the average pore spacing of compacted bentonite at dry density of $1.0 \mathrm{~kg} / \mathrm{dm}^{3}$ [18], the solubility of $\mathrm{CaCO}_{3}$ in the porewater should be increased by a factor of 1.2. This value corresponds to a saturation index of 0.08 which means that the small pore effect to the value of $K_{S p \mathrm{CaCO}_{3}}$ in the porewater under the experimental conditions can be neglected.

Based thereon, the $\gamma_{ \pm}$values in the porewater are estimated and the resulting value are shown in Figure 7. The values are estimated for the porewater composition in the precipitation zone at $x=5.25$ and $5.75 \mathrm{~mm}$. Beyond $x=5.75 \mathrm{~mm}$ the concentration of free $\mathrm{Ca}^{2+}$ ions were below detection limit, thus the $\gamma_{ \pm}$values cannot be obtained. Figure 7 also shows the theoretical approximation of $\gamma_{ \pm}$values for a direct comparison with the experimental result. The theoretical $\gamma_{ \pm}$values are obtained from the average of individual activity coefficients of $\mathrm{Ca}^{2+}$ and $\mathrm{CO}_{3}{ }^{2-}$ ions which calculated using PHREEQC code [50]. The equilibrium constants used for speciation calculation are listed in 
Table 3. Note that the concentration of free ions corresponding to the ionic strength of the porewater after the electromigration experiment are different than that of the initial condition. The theoretical $\gamma_{ \pm}$values are different depending on the location because the ionic strength of the porewater after the experiment is not spatially uniform. Nonetheless, it is evident that the experimentally determined $\gamma_{ \pm}$values within the range of $\mathrm{pH}$ under the experimental conditions are smaller than the theoretical values approximately by a factor of three and eight, using $K_{s p}$ value of $10^{-6.4}$ and $10^{-7.54}$, respectively.

\subsection{Pore water chemistry in bentonite}

In line with previous studies [30,51], the lower activity coefficient than the theoretical approximation could be attributed to the interaction of the bentonite surface with the porewater. Therefore, the ions in the porewater experience stronger coulombic interactions than in the bulk water. For example, previous study reported that the activity of the porewater becomes less than unity when the total water content is less than 0.40 [52]. On the other hand, the results of this study show that such deviation was found for dissolved $\mathrm{Ca}^{2+}$ and $\mathrm{CO}_{3}{ }^{2-}$ ions in bentonite with total water content of 0.65 , which corresponds to the dry density of $1.0 \mathrm{~kg} / \mathrm{dm}^{3}$ used in this study. This difference is possibly because of the charged ions experiencing stronger effects of the bentonite surface than water molecules and/or the difference in ionic strength of the porewater. Nevertheless, this result confirms that the activity coefficient in the porewater is significantly lower than that in free water.

The fact that the experimental value of activity coefficient in the porewater is lower than the theoretical approximation has important implications in the safety 
assessment for radioactive waste geological disposal. For example, lower activity coefficient directly related to higher solubilities of radionuclides in the porewater. The solubilities of radionuclides are the source term for modelling fate and transport of radionuclides through engineered barriers. Knowing the solubilities of key radionuclides is one of the most important issues for performance assessment [53]. The activity coefficient also has deeper impact in transport, chemical speciation and reaction in bentonite. Therefore, further reexamination of activity coefficient approximation in the porewater is critical for safety assessment in engineered barrier of radioactive waste disposal.

\section{Conclusions}

The precipitation of $\mathrm{CaCO}_{3}$ in compacted Na-bentonite with dry density of $1.0 \mathrm{~kg} / \mathrm{dm}^{3}$ from counter diffusion of $\mathrm{Ca}^{2+}$ and $\mathrm{HCO}_{3}{ }^{-} / \mathrm{CO}_{3}{ }^{2-}$ ions enhanced by electrokinetic method were successfully achieved. The sequential extraction developed in this study provide a practical method to distinguish the free $\mathrm{Ca}^{2+}$ ions from the exchangeable and precipitates species. After the experiment, the Na-bentonite sample changed to three different types: Ca-, Ca-/Na-, and Na-bentonite. The occurrence of $\mathrm{CaCO}_{3}$ precipitates was observed in the Ca- and Ca-/Na-bentonite zone. SEM/EDS images and X-ray diffraction patterns suggested that the $\mathrm{CaCO}_{3}$ precipitates were likely amorphous phase. The experimentally determined mean activity coefficients of $\mathrm{Ca}^{2+}$ and $\mathrm{CO}_{3}{ }^{2-}$ were at least smaller by a factor of three than the theoretical approximation. This result raised the importance of reexamination of the activity coefficient in the porewater, because it is a critical parameter in safety assessment of geological disposal. 


\section{Acknowledgements}

The experiment with radiotracer were performed at the Central Institute of Isotope

Science, Hokkaido University. The SEM/EDS analysis were conducted at the High

Voltage Electron Microscope Laboratory, Center for Advanced Research of Energy and Materials, Hokkaido University. This work was partly supported by the JSPS Grant-inAid for Scientific Research (S) [grant number 24226021]; the JSPS Grant-in-Aid for Challenging Exploratory Research [grant number 23656581]; and RISET-Pro Kemenristekdikti Indonesia [grant number 74/RISET-Pro/FGS/III/2016]. 


\section{References}

[1] Japan Atomic Energy Agency, The Federation of Electric Power Companies of Japan. Second progress report on research and development for TRU waste disposal in japan - repository design, safety assessment and means of implementation in the generic phase. Tokai: JAEA; 2007. (JAEA-Review 2007010).

[2] International Atomic Energy Agency. Disposal of Radioactive Waste. Vienna: IAEA; 2011. (IAEA Safety Standards Series No. SSR-5).

[3] Tinseau E, Bartier D, Hassouta L, et al. Mineralogical characterization of the Tournemire argillite after in situ interaction with concretes. Waste Manag. 2006;26(7):789-800.

[4] Gaucher EC, Blanc P. Cement/clay interactions - A review: Experiments, natural analogues, and modeling. Waste Manag. 2006;26(7):776-788.

[5] Jenni A, Mäder U, Lerouge C, et al. In situ interaction between different concretes and Opalinus Clay. Phys. Chem. Earth. 2014;70-71:71-83.

[6] Moyce EBA, Rochelle C, Morris K, et al. Rock alteration in alkaline cement waters over 15 years and its relevance to the geological disposal of nuclear waste. Appl. Geochemistry. 2014;50:91-105.

[7] Steefel CI, Lichtner PC. Diffusion and reaction in rock matrix bordering a hyperalkaline fluid-filled fracture. Geochim. Cosmochim. Acta. 1994;58(17):3595-3612.

[8] Gaboreau S, Prêt D, Tinseau E, et al. 15 years of in situ cement-argillite interaction from Tournemire URL: Characterisation of the multi-scale spatial heterogeneities of pore space evolution. Appl. Geochemistry. 2011;26(12):21592171.

[9] Smith KF, Bryan ND, Swinburne AN, et al. U(VI) behaviour in hyperalkaline calcite systems. Geochim. Cosmochim. Acta. 2015;148:343-359.

[10] Hellebrandt SE, Hofmann S, Jordan N, et al. Incorporation of Eu(III) into calcite under recrystallization conditions. Sci. Rep. 2016;6:1-10. 
[11] Morse JW, Arvidson RS, Lüttge A. Calcium carbonate formation and dissolution. Chem. Rev. 2007;107(2):342-381.

[12] Gebauer D, Völkel A, Cölfen H. Stable prenucleation calcium carbonate clusters. Science. 2008;322(5909):1819-1822.

[13] Tartakovsky AM, Redden G, Lichtner PC, et al. Mixing-induced precipitation : Experimental study and multiscale numerical analysis. Water Resour. Res. 2008;44:1-19.

[14] Redden $\mathrm{G}$, Fox D, Zhang $\mathrm{C}$, et al. $\mathrm{CaCO}_{3}$ precipitation, transport and sensing in porous media with in situ generation of reactants. Environ. Sci. Technol. 2014;48(1):542-549.

[15] Stack AG, Fernandez-Martinez A, Allard LF, et al. Pore-size-dependent calcium carbonate precipitation controlled by surface chemistry. Environ. Sci. Technol. 2014;48(11):6177-6183.

[16] Genovese D, Montalti M, Otálora F, et al. Role of $\mathrm{CaCO}_{3}{ }^{\circ}$ neutral pair in calcium carbonate crystallization. Cryst. Growth Des. 2016;16(8):4173-4177.

[17] Bourg IC, Bourg ACM, Sposito G. Modeling diffusion and adsorption in compacted bentonite: A critical review. J. Contam. Hydrol. 2003;61(1-4):293302.

[18] Kozaki T, Inada K, Sato S, et al. Diffusion mechanism of chloride ions in sodium montmorillonite. J. Contam. Hydrol. 2001;47(2-4):159-170.

[19] Van Loon LR, Glaus MA, Müller W. Anion exclusion effects in compacted bentonites: Towards a better understanding of anion diffusion. Appl. Geochemistry. 2007;22(11):2536-2552.

[20] Glaus MA, Frick S, Rossé R, et al. Comparative study of tracer diffusion of HTO, ${ }^{22} \mathrm{Na}^{+}$and ${ }^{36} \mathrm{Cl}^{-}$in compacted kaolinite, illite and montmorillonite. Geochim. Cosmochim. Acta. 2010;74(7):1999-2010.

[21] Stack AG. Precipitation in Pores : A Geochemical Frontier. Rev. Mineral. Geochemistry. 2015;80(1):165-190.

[22] Tournassat C, Vinsot A, Gaucher EC, et al. Chapter 3 - Chemical conditions in 
clay-rocks. In: Tournassat C, Steefel CI, Bourg IC, et al., editors. Natural and engineered Ccay barriers. Amsterdam (Netherlands): Elsevier; 2015.p.71-100.

[23] Vinsot A, Mettler S, Wechner S. In situ characterization of the CallovoOxfordian pore water composition. Phys. Chem. Earth. 2008;33:S75-S86.

[24] Muurinen A. Development and testing of analysis methods for bentonite porewater. Helsinki: Posiva Oy; 2001. (Working Report 2001-07).

[25] Grambow B, Landesman C, Ribet S. Nuclear waste disposal: I. Laboratory simulation of repository properties. Appl. Geochemistry. 2014;49:237-246.

[26] Fernández AM, Baeyens B, Bradbury M, et al. Analysis of the porewater chemical composition of a Spanish compacted bentonite used in an engineered barrier. Phys. Chem. Earth, Parts A/B/C. 2004;29(1):105-118.

[27] Appelo CAJ, Vinsot A, Mettler S, et al. Obtaining the porewater composition of a clay rock by modeling the in- and out-diffusion of anions and cations from an insitu experiment. J. Contam. Hydrol. 2008;101(1-4):67-76.

[28] Fernández AM, Sánchez-Ledesma DM, Tournassat C, et al. Applying the squeezing technique to highly consolidated clayrocks for pore water characterisation: Lessons learned from experiments at the Mont Terri Rock Laboratory. Appl. Geochemistry. 2014;49:2-21.

[29] Tachi Y, Ochs M, Suyama T. Integrated sorption and diffusion model for bentonite. Part 1: clay-water interaction and sorption modeling in dispersed systems. J. Nucl. Sci. Technol. 2014;51(10):1177-1190.

[30] Torikai Y, Sato S, Ohashi H. Thermodynamic properties of water in compacted sodium montmorillonite. Nucl. Technol. 1996;115(1):73-80.

[31] Maes N, Moors H, Dierckx A, et al. The assessment of electromigration as a new technique to study diffusion of radionuclides in clayey soils. J. Contam. Hydrol. 1999;36(3-4):231-247.

[32] Higashihara T, Kinoshita K, Sato S, et al. Electromigration of sodium ions and electro-osmotic flow in water-saturated, compacted Na-montmorillonite. Appl. Clay Sci. 2004;26(1-4):91-98. 
[33] Beauwens T, De Cannière P, Moors H, et al. Studying the migration behaviour of selenate in Boom Clay by electromigration. Eng. Geol. 2005;77(3-4):285-293.

[34] Tanaka S, Noda N, Sato S, et al. Electrokinetic study of migration of anions, cations, and water in water-saturated compacted sodium montmorillonite. J. Nucl. Sci. Technol. 2011;48(3):454-462.

[35] Tanaka S. Gypsum precipitation enhanced by electrokinetic method and porewater chemistry in compacted montmorillonite. Appl. Clay Sci. 2018;161:482-493.

[36] Kozaki T, Fujishima A, Sato S, et al. Self-diffusion of sodium ions in compacted sodium montmorillonite. Nucl. Technol. 1998;121(1):63-69.

[37] Plummer LN, Busenberg E. The solubilities of calcite, aragonite and vaterite in $\mathrm{CO}_{2}-\mathrm{H}_{2} \mathrm{O}$ solutions between 0 and $90^{\circ} \mathrm{C}$, and an evaluation of the aqueous model for the system $\mathrm{CaCO}_{3}-\mathrm{CO}_{2}-\mathrm{H}_{2} \mathrm{O}$. Geochim. Cosmochim. Acta. 1982;46(6):10111040.

[38] Hull H, Turnbull AG. A thermochemical study of monohydrocalcite. Geochim. Cosmochim. Acta. 1973;37(3):685-694.

[39] Kralj D, Brečević L. Dissolution kinetics and solubility of calcium carbonate monohydrate. Colloids Surfaces A Physicochem. Eng. Asp. 1995;96(3):287-293.

[40] Brečević L, Nielsen AE. Solubility of amorphous calcium carbonate. J. Cryst. Growth. 1989;98(3):504-510.

[41] Clarkson JR, Price TJ, Adams CJ. Role of metastable phases in the spontaneous precipitation of calcium carbonate. J. Chem. Soc. Faraday Trans. 1992;88(2):243-249.

[42] Wang Y, Zeng M, Meldrum FC, et al. Using confinement to study the crystallisation pathway of calcium carbonate. Cryst. Growth Des. 2017;17(12):6787-6792.

[43] Takeda S, Shima S, Kimura H, et al. The aqueous solubility and speciation analysis for uranium, neptunium and selenium by the geochemical code (EQ3/6). Tokai: JAERI; 1995. (JAERI Research 95-069). 
[44] Kim SS, Baik MH, Kang KC, et al. Solubilities of actinides in a domestic groundwater and a bentonite porewater calculated by using PHREEQC. J. Ind. Eng. Chem. 2008;14(6):739-746.

[45] Kellermeier M, Picker A, Kempter A, et al. A straightforward treatment of activity in aqueous $\mathrm{CaCO}_{3}$ solutions and the consequences for nucleation theory. Adv. Mater. 2014;26(5):752-757.

[46] Rijniers LA, Huinink HP, Pel L, et al. Experimental evidence of crystallization pressure inside porous media. Phys. Rev. Lett. 2005;94(7):23-26.

[47] Prieto M. Nucleation and supersaturation in porous media (revisited). Mineral. Mag. 2014;78(6):1437-1447.

[48] DeYoreo JJ, Vekilov PG. Principles of crystal nucleation and growth. Rev. Mineral. Geochemistry. 2003;54(1):57-93.

[49] Stumm W, Morgan JJ. Aquatic chemistry: Chemical equilibria and rates in natural waters. 3rd ed. New York (NY): Wiley; 1995.

[50] Parkhurst DL, Appelo CAJ. Description of input and examples for PHREEQC version 3--A computer program for speciation, batch-reaction, one-dimensional transport, and inverse geochemical calculations. Denver (CO): U.S. Geological Survey; 2013.

[51] Serafeimidis K, Anagnostou G. The solubilities and thermodynamic equilibrium of anhydrite and gypsum. Rock Mech. Rock Eng. 2014;48(1):15-31.

[52] Sato H. Thermodynamic model on swelling of bentonite buffer and backfill materials. Phys. Chem. Earth. 2008;33:538-543.

[53] McKinley IG, Savage D. Comparison of solubility databases used for HLW performance assessment. J. Contam. Hydrol. 1996;21(1-4):335-350. 
Table 1. Tracers and Solutions used in the electromigration experiment.

\begin{tabular}{lcccc}
\hline $\begin{array}{l}\text { Experiment } \\
\text { Number }\end{array}$ & Tracer & \multicolumn{3}{c}{ Solution } \\
\cline { 2 - 5 } & & $\begin{array}{c}\text { Solution used to } \\
\text { saturate the } \\
\text { compacted Na- } \\
\text { bentonite }\end{array}$ & Anolyte & Catholyte \\
& \multicolumn{4}{c}{$0.7 \mathrm{M} \mathrm{NaHCO}_{3}$} \\
Experiment 1 & ${ }^{45} \mathrm{Ca}$ & $0.7 \mathrm{M} \mathrm{NaHCO}_{3}$ & $1 \mathrm{M} \mathrm{NaCl}^{45} \mathrm{CaCl}_{2}$ & $0.7 \mathrm{M} \mathrm{NaH}^{14} \mathrm{CO}_{3}$ \\
Experiment 2 & ${ }^{14} \mathrm{C}$ & $0.7 \mathrm{M} \mathrm{NaH}^{14} \mathrm{CO}_{3}$ & $1 \mathrm{M} \mathrm{CaCl}_{2}$ & $0.7 \mathrm{M} \mathrm{NaHCO}_{3}$ \\
Experiment 3 & - & $0.7 \mathrm{M} \mathrm{NaHCO}_{3}$ & $1 \mathrm{M} \mathrm{CaCl}_{2}$ & $0.7 \mathrm{M} \mathrm{NaHC}^{2}$
\end{tabular}


Table 2. Recoveries of free and exchangeable ${ }^{45} \mathrm{Ca}^{2+}$ ions in sequential extraction.

\begin{tabular}{cccccc}
\hline \multirow{2}{*}{ Sample } & ${ }^{45} \mathrm{Ca}^{2+}$ radioactivities $(\mathrm{cpm})$ & \multicolumn{3}{c}{ Recovery $(\%)$} \\
\cline { 2 - 6 } & 1st batch & 2nd batch & 1st batch & $2^{\text {nd }}$ batch & Average \\
\hline${ }^{45} \mathrm{Ca}^{2+}$ aqueous & 35864 & 35820 & & & \\
${ }^{45} \mathrm{Ca}^{2+}$ solid & 48096 & 48540 & & & \\
\hline Extraction by saturated $\mathrm{CaCO}_{3}$ & solution & & & \\
$1^{\text {st }}$ & 33037 & 33532 & 92.1 & 93.6 & 92.9 \\
$2^{\text {nd }}$ & 457 & 484 & 1.3 & 1.4 & 1.3 \\
Total & 33493 & 34016 & 93.4 & 95.0 & 94.2 \\
\hline Extraction by 1 M HCl & & & & \\
$1^{\text {st }}$ & 45570 & 45780 & 94.7 & 94.3 & 94.5 \\
$2^{\text {nd }}$ & 1383 & 1070 & 2.9 & 2.2 & 2.5 \\
Total & 46953 & 46850 & 97.6 & 96.5 & 97.1 \\
\hline
\end{tabular}


Table 3. Equilibrium constant for speciation calculation at a temperature of $298 \mathrm{~K}$ [50].

\begin{tabular}{cc}
\hline Reaction & $\log \mathrm{K}$ \\
\hline $\mathrm{Ca}^{2+}+\mathrm{H}_{2} \mathrm{O} \leftrightarrow \mathrm{Ca}(\mathrm{OH})^{+}+\mathrm{H}^{+}$ & -12.78 \\
$\mathrm{Ca}^{2+}+\mathrm{CO}_{3}^{2-} \leftrightarrow \mathrm{CaCO}_{3}^{0}$ & 3.224 \\
$\mathrm{Ca}^{2+}+\mathrm{CO}_{3}^{2-}+\mathrm{H}^{+} \leftrightarrow \mathrm{CaHCO}_{3}^{+}$ & 11.435 \\
$\mathrm{CO}_{2}+\mathrm{H}_{2} \mathrm{O} \leftrightarrow \mathrm{HCO}_{3}^{-}+\mathrm{H}^{+}$ & -6.352 \\
$\mathrm{HCO}_{3}^{-} \leftrightarrow \mathrm{CO}_{3}^{2-}+\mathrm{H}^{+}$ & -10.329 \\
$\mathrm{Na}^{+}+\mathrm{CO}_{3}^{2-} \leftrightarrow \mathrm{NaCO}_{3}^{-}$ & 1.27 \\
$\mathrm{Na}^{+}+\mathrm{HCO}_{3}^{-} \leftrightarrow \mathrm{NaHCO}_{3}$ & -0.25 \\
$\mathrm{Na}^{+}+\mathrm{H}_{2} \mathrm{O} \leftrightarrow \mathrm{NaOH}+\mathrm{H}^{+}$ & -14.18 \\
\hline
\end{tabular}




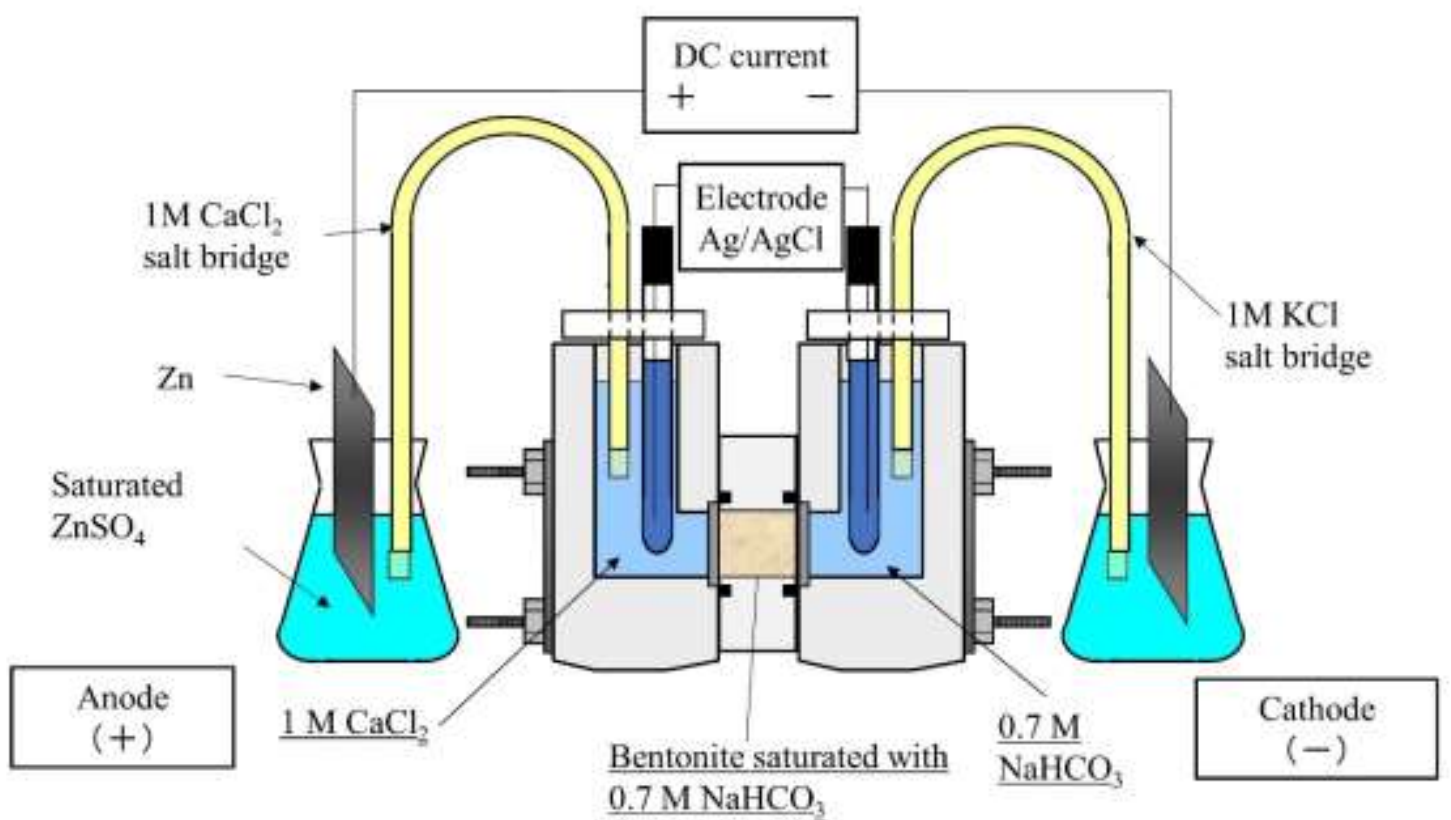

Figure 1. Schematic electromigration experiment set up. 


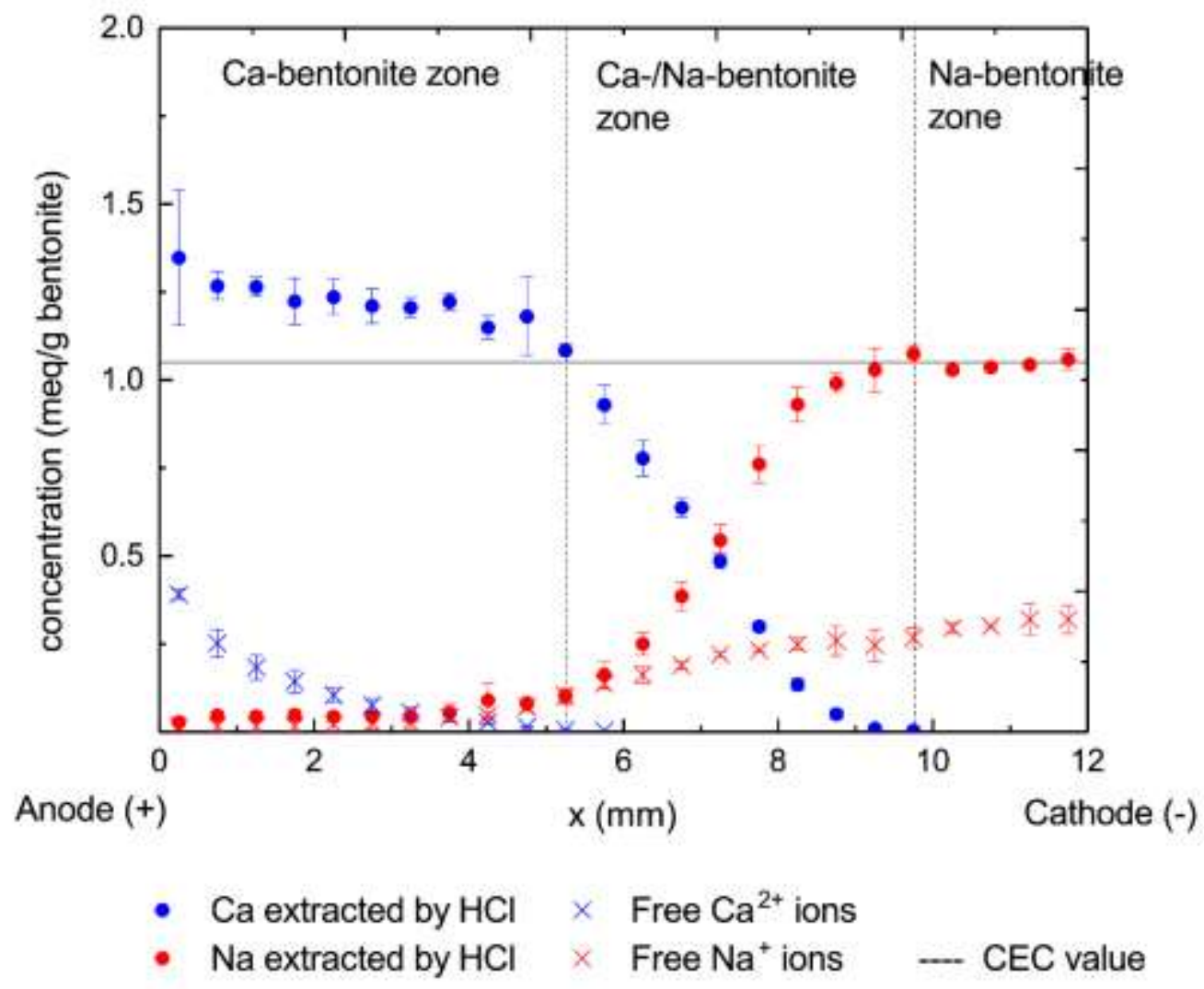

Figure 2. Spatial distribution of $\mathrm{Ca}^{2+}$ and $\mathrm{Na}^{+}$ions in compacted montmorillonite after 16 hours of electromigration experiment. The free $\mathrm{Ca}^{2+}$ and $\mathrm{Na}^{+}$ions are their respective concentration from extraction with saturated $\mathrm{CaCO}_{3}$ solution. The figure has the plotting concentrations (meq/g-dry bentonite) per sliced bentonite sample versus the position of the distance of the centre of each slice from the anode side. The acid extractable $\mathrm{Ca}^{2+}$ and $\mathrm{Na}^{+}$from sequential extraction are the concentration of $\mathrm{Ca}^{2+}$ and $\mathrm{Na}^{+}$ions as exchangeable cations and solid phases. The horizontal straight line is the CEC value of bentonite sample which equals $1.05 \mathrm{meq} / \mathrm{g}$-dry bentonite. The error bars are calculated from the standard deviation of average value in triplicate experiments. 


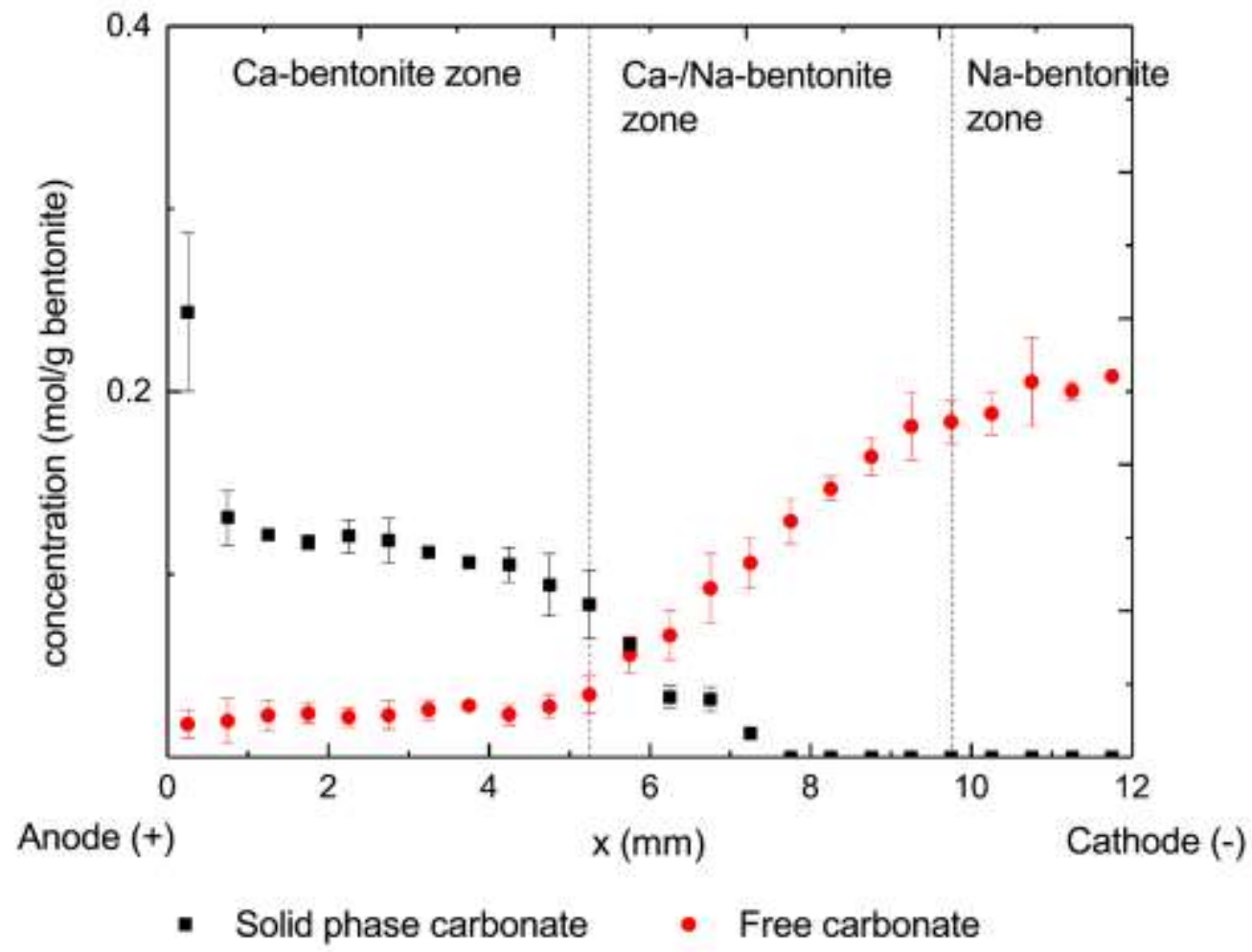

Figure 3. Spatial distribution of carbonate as free ions and solid phase in compacted bentonite after 16 hours of electromigration. 


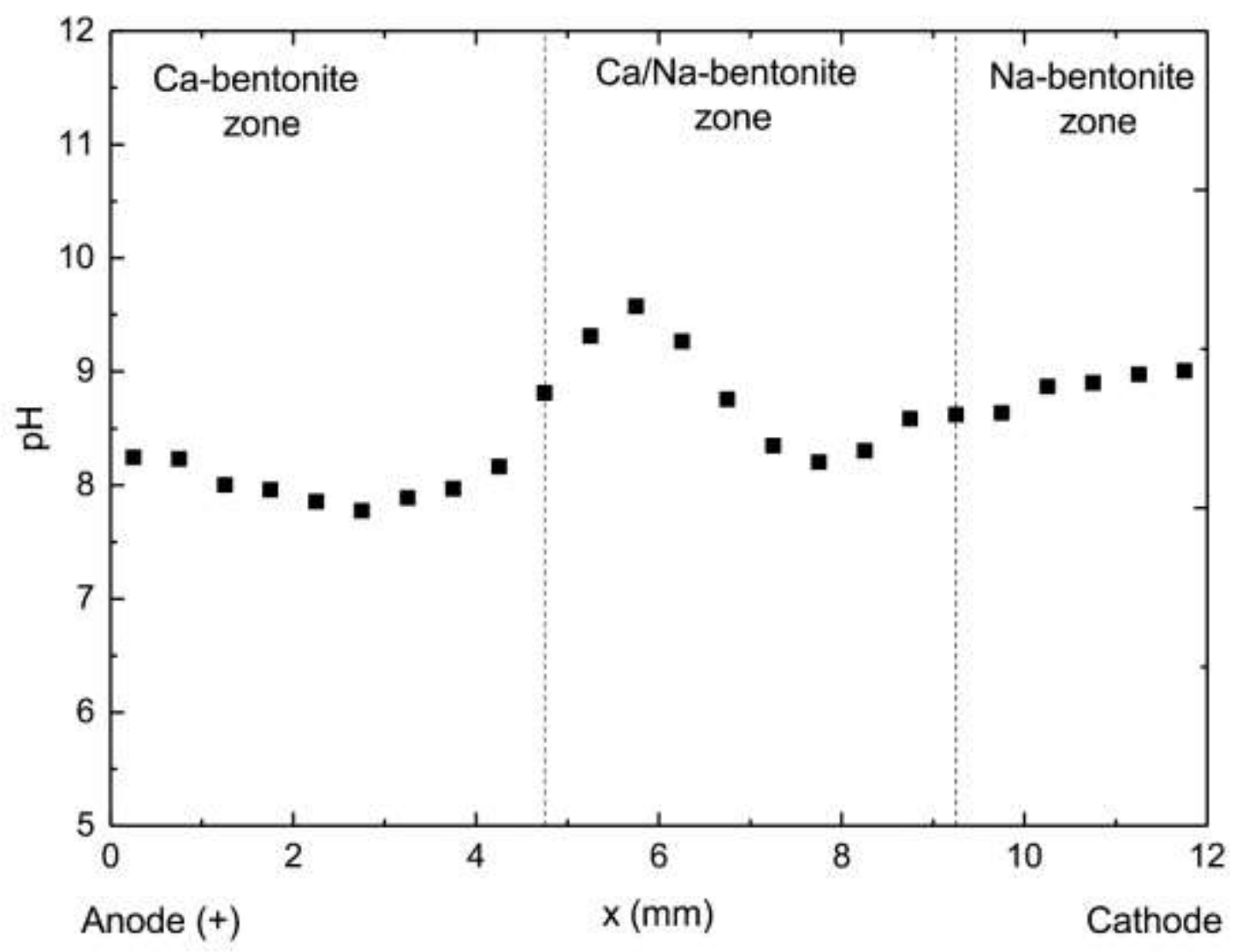

Figure 4. Spatial distribution of $\mathrm{pH}$ of sliced bentonite sample dispersed in $10 \mathrm{ml}$ deionized water. 

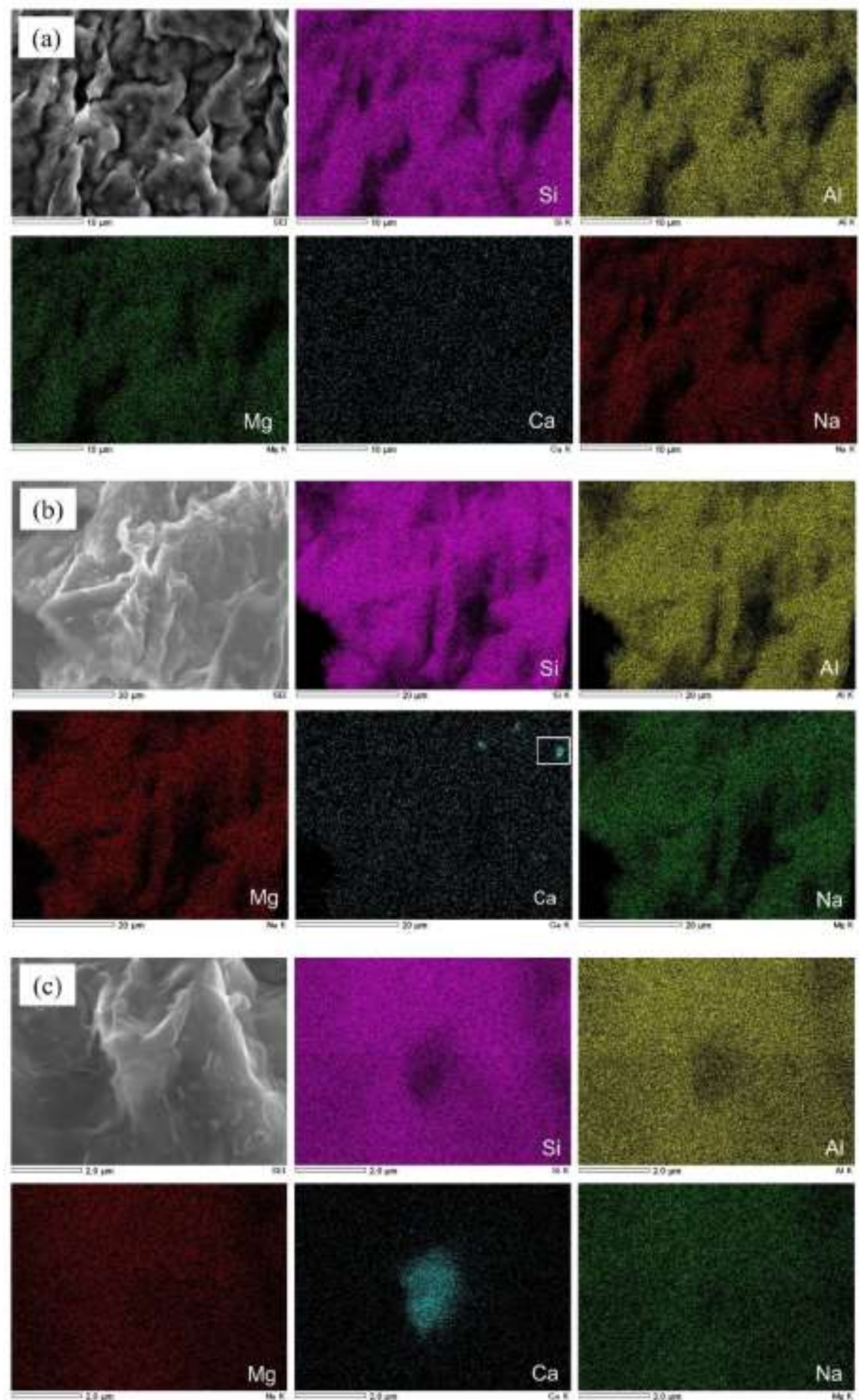

Figure 5. SEM/EDS images of (a) initial bentonite, sliced bentonite sample at (b) $x=7.75$ $\mathrm{mm}$ and (c) magnification of an area of white square in the image (b). The bright spots in Ca-map in image (b) and (c) show rich areas with relatively higher concentration of $\mathrm{Ca}$ which were not detectable in image (a). 


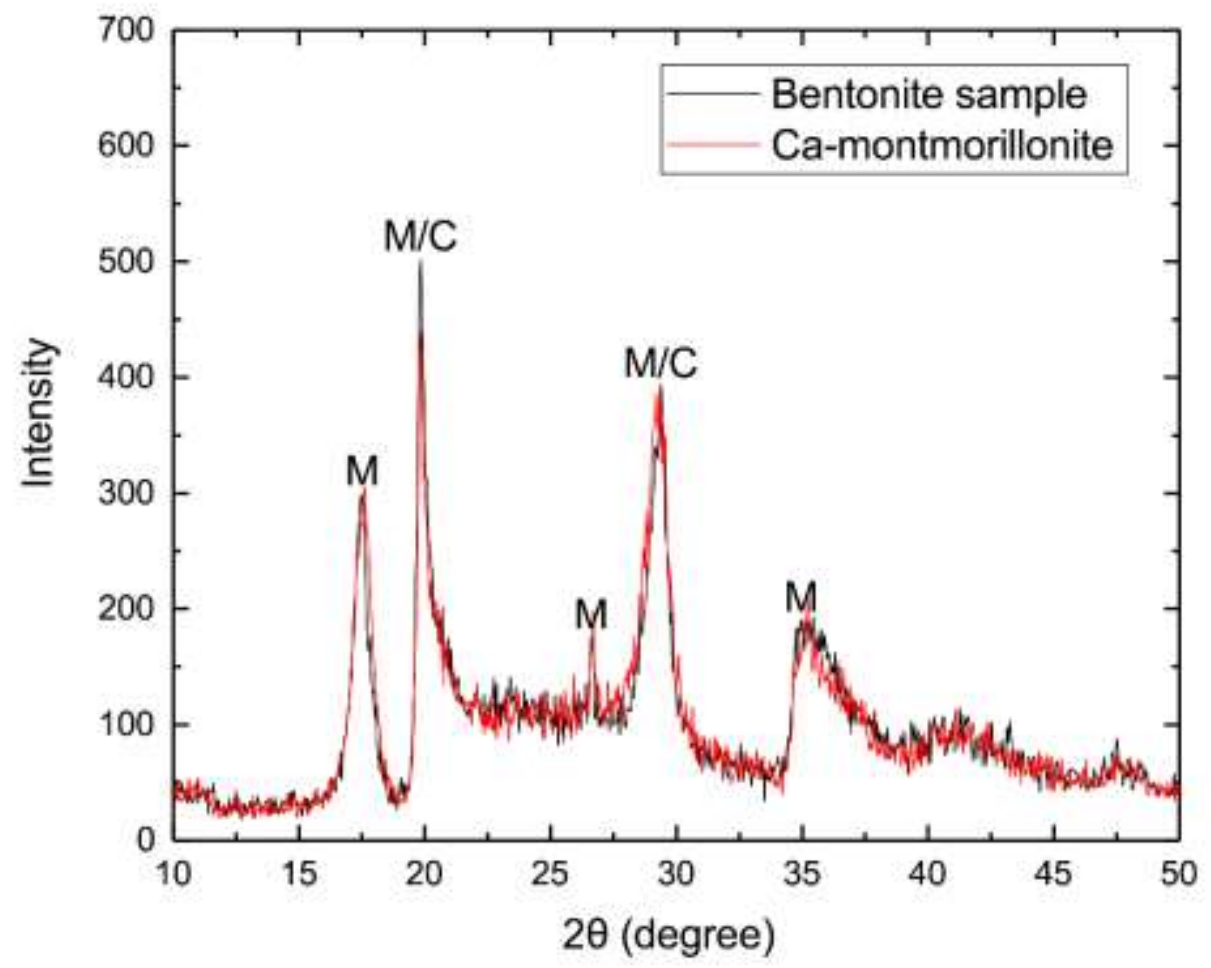

Figure 6. X-ray diffraction patterns of bentonite sample at $x=0.5 \mathrm{~mm}$ distance from the anode side after the electromigration experiment compared with $\mathrm{Ca}$-bentonite (M: Camontmorillonite, C: calcite). 


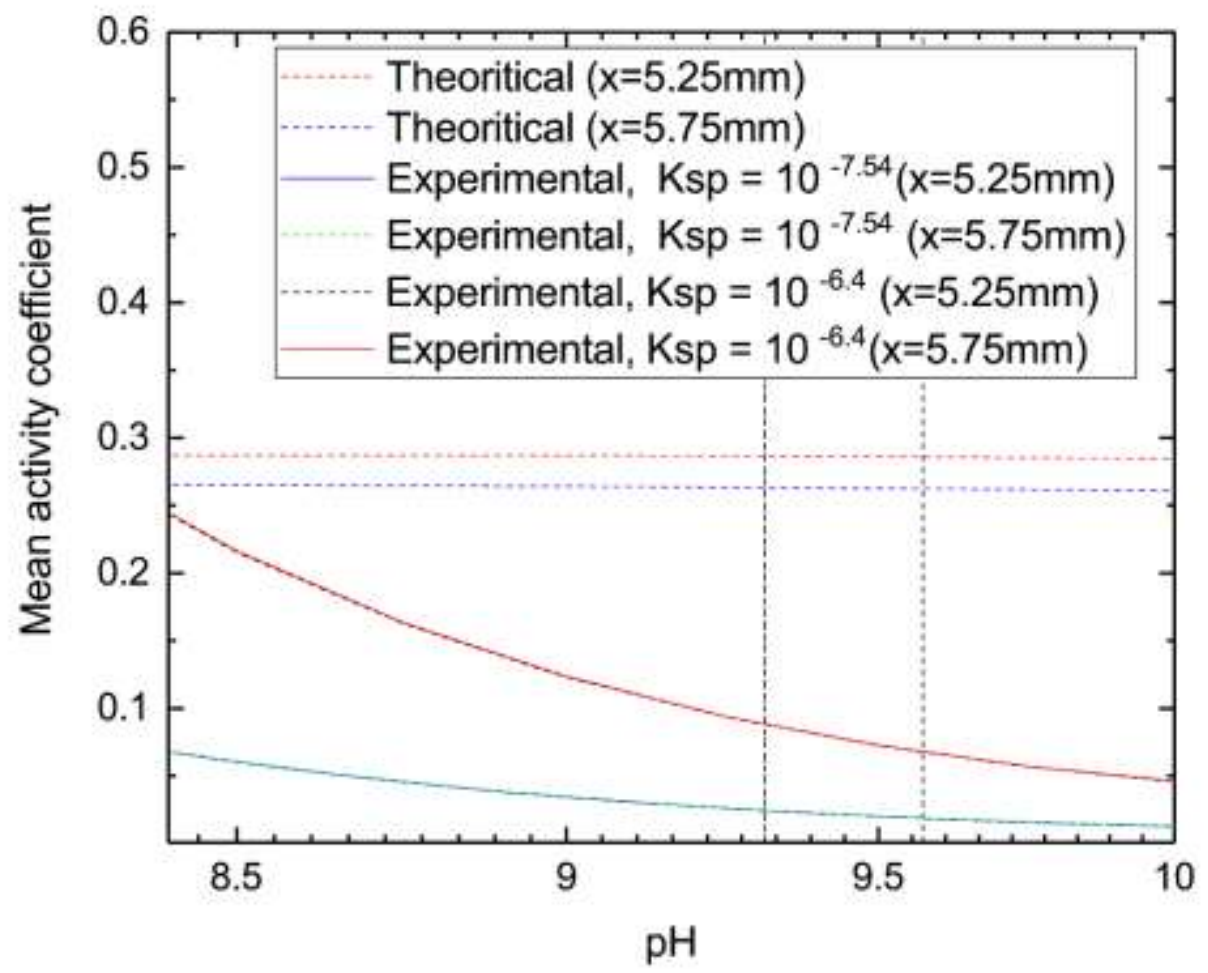

Figure 7. Experimentally determined and theoretical mean activity coefficients calculated using PHREEQC code in the porewater at $x=5.25$ and $5.75 \mathrm{~mm}$. The vertical dash lines are the $\mathrm{pH}$ of dispersed bentonite in deionized water which were obtained from the experiment. 